\title{
Understanding the Mechanisms of Neoliberal Control: Lifelong Learning, flexibility and Knowledge Capitalism
}

\author{
Mark Olssen
}

I wish to demonstrate in this paper that Foucault's conception of governmentality provides a powerful tool for understanding developments in relation to learning and education.

My thesis will be that the radicalness of Foucault's thesis is much greater than many writers on Foucault seem to realise.

For what is offered by Foucault's conception I will argue is a new version of superstructural sociology which provides a means of understanding how educational and economic practices mutually condition and adapt to each other while avoiding the excesses that plagued Marxist analyses in the later $20^{\text {th }}$ century which represented such processes as the outcome of a necessary determination.

I will identify lifelong learning as a specifically neoliberal form of state reason which has manifested a uniformly consistent - albeit not exclusive concern - of serving dominant economic interests

The prospects for moving beyond it depend, I will claim, on whether the structures of learning created can be harnessed for other ends; that is, whether embryonic within the discursive programme of lifelong learning is the possibility of linking the discourse to a progressive emancipatory project based upon egalitarian politics and social justice. Is it indeed possible that we can all be inhabitants of a genuinely learning society? And what would such a society look like?

By way of structure, my paper will comprise the following sections: first, an elucidation of Foucault's concept of governmentality; second, the inherent dangers afflicting lifelong learning programmes of being harnessed in the interests of neoliberal reason, through discourses of flexibility or flexible specialisation; and third, the possibilities and prospects for lifelong learning to break out of its neoliberal shell transforming itself away from discourses of neoliberal flexibilisation to representing discourses of democratisation and social justice. 


\section{Foucault's concept of governmentality}

Foucault's concept of governmentality refers to the structures of power by which conduct is organised, and by which governance is aligned with the self-organising capacities of individual subjects.

It deals with particular models of governing individuals. Foucault developed this conception of power in the late 1970s in his courses at the Collège de France in order to provide a more macro dimension to enable him to theorise models of power which dealt with of collective governance.

While in his genealogical studies he had analysed micro and disciplinary dimensions of pastoral power and bio-power, giving shape to modern institutions such as schools, prisons and hospitals,

partly no doubt as a response to the sorts of criticisms that Duccio Trombadori levelled at him in the interviews of 1978, concerning the overly 'localistic' nature of his analysis of power, rendering it impossible to insert individual events within a broader political perspective, that Foucault shifted his analysis to represent the collective dimensions of governmental power as manifested by such agencies as the modern state.

His aim was not, however, to ascertain the legitimacy to state power, or the management of states, but to understand the nature of governmental rationalities linked to specific technologies in terms of how collective power was exercised over individuals.

"How", not in the sense of "How does it manifest itself?" but "By what means is it exercised?" and "What happens when individuals exert (as they say) power over others?" (1982: 217)

This is what Foucault meant by government, which referred to a form of activity aimed to guide and shape conduct.

To govern thus designates "the way in which the conduct of individuals or of groups might be directed....[it] is to structure the possible field of action of others" (p.221) 
In 'The Subject and Power' (1982: 221) essay Foucault alludes to the equivocal nature of the term conduct as it pertains to power relations. For, on the one hand it pertains to "lead[ing] others (according to mechanisms of coercion which are, to varying degrees strict)" and, on the other "a way of behaving within a more or less open field of possibilities" (pp. 220-221) ${ }^{1}$. Hence, he says (p. 221) "The exercise of power consists in guiding the possibility of conduct and putting in order the possible outcome". And this is what makes the issue of power, "less a confrontation between two adversaries...than a question of government" (p. 221).

To speak of government or power is to presuppose that "certain people exercise power over others", which is to speak of "relationships" (p. 217). In this sense, power relations are distinct from "objective abilities" as well as from "relations of communication", yet they can be "grasped in the diversity of their logical sequence, their abilities, and their interrelationships" (p. 219).

What is important to see here is that for Foucault power is not an entity, but rather a relation offorces. What constitutes the specific nature of power is that it is a "set of actions upon other actions"; that is, it is

a total structure of actions brought to bear upon possible actions; it incites, it induces, it seduces, it makes it easier or more difficult; in the extreme it constrains or forbids absolutely; it is nevertheless always a way of acting upon an acting subject or acting subjects by virtue of their acting or being capable of action. (p. 220)

What is also important is that power is exercised strategically only over free subjects. By the word strategy Foucault means three things:

First, to designate the means employed to attain a certain end, it is a question of rationality functioning to arrive at an objective. Second, to designate the manner in which a partner in a certain game acts with regard to what he thinks should be the action of the others and what he considers the others think to be his own; it is the way in which one seeks to have the advantage over others. Third...it is a question... of the means used to obtain victory. (pp. $224-225$ )

A power strategy then is "the totality of means put into operation to implement power effectively or to maintain it" (p. 225) To the extent that such relations of power are open and fluid, there is a degree of instability permitting the possibility of reversal, or modification. In this sense, while hegemonies exist, they exist precariously. To the extent to which relations of power have become congealed, or fixed, it represents a "strategic situation, more or less taken for granted and consolidated by means of a long term confrontation between adversaries" (p. 226). 
In a 1978 lecture at the Collège de France, Foucault (1991) introduces the term governmentality to supplement pastoral power and biopower. Governmentality has dual functions as individualising and totalising, in shaping both individuals and populations, in order to understand the collective exercise of power.

If 'bio-power' referred to disciplinary power introduced in the early modern period in order to rationalise the problems afflicting populations, governmentality pertains to the specificity of power relations with its concern to shape conduct as part of broader issue involving the political exercise of power.

It includes "techniques and procedures for directing human behaviour" (1997c: 81). It pertains, he says (1991: 87-88) to "a concern with the art of government... of how to be ruled, how strictly, by whom, to what end, by what methods, etc". In addition, the concept can be applied to the family, religion, the economy, as well as the state. In its most general sense it pertains to the "problematic of government in general" (p. 88) and articulates "a kind of rationality" (p. 89).

For Foucault (1991: 90), the art of government is also concerned with the issue of security, of stabilising the fragile link between ruler and ruled, of rendering it legitimate, "to identify dangers... to develop the art of manipulating relations of force that will allow the Prince to ensure the protection of his principality".

The concept of security is, along with governmentality, a central concept for Foucault, and is concerned with the issue of how the state deals with unpredictable events, how it evaluates and calculates the costs and consequences, and how it manages populations within constraint, rather than through the imposition of rule. Indeed, "one need[s] to analyze the series: security, population, government" (1991: 87) as part of a combined approach.

While sovereignty is concerned with the problem of rule through the imposition of Law, security is concerned with the management of populations. The intersection of security and government occurs with the concern for the regulation of populations" and the search for "mechanisms capable of ensuring its regulation" (1997a: 67). While the issue of security is relevant in all periods of history, it became of increased concern in the $18^{\text {th }}$ century, and affected the form and practice of government. 


\section{Historicized rationalities}

In his later works and interviews, Foucault's presents the outline of a genealogy of power, tracing the different historical modalities in the way models of power have functioned at different periods.

In lectures given in 1978/9 and specifically in the Tanner lectures (see 2000a), Foucault argues that a history of the forms of rationality by which power operates is more effective than an abstract conception or model of power. Power is rationalised in different periods in different ways, yet the basis of its rationalisation is different from the rationality of economic processes, or of scientific discourses. What he is concerned to do is ascertain the form of rationality at stake. Although he says (2001a: 325) that "for several centuries the state has been one of the most redoubtable forms of human government", it is important to examine the "nascent state rationalities" in the course of their historical development if we are to understand the paradoxes of our present forms of government in relation to its management of the learning of its subjects.

In this he identifies a variety of historically situated rationalities, including pastoral power, raison d'etat, Polizei, liberal, and neoliberal reason, which together span the period from ancient times until the present, all comprising specific arts of government or forms of governmentality. Although Foucault's interests were more generally confined to the arts of government of populations, my interest in this paper is to ascertain the relevance of his approach specifically for discourses of knowledge and learning, structured as they are in relation to particular agendas of interest and power.

\section{Lifelong learning as a neoliberal art of government}

In Foucault's sense, lifelong learning represents a model of governing individuals in their relation to the collective.

More specifically it constitutes a technology of control.

Its specific governmental significance can be seen in the EU which has declared lifelong learning as a central educational project, in its quest to integrate 25 populations into a new European identity. As the European Commission (2002: 4) has stated:

Lifelong learning is an overarching strategy of European co-operation in education and training policies and for the individual. The lifelong learning approach is an essential policy strategy for the development of citizenship, social cohesion, employment and for individual fulfilment. 
As in the Lisbon Memorandum on lifelong learning, (European Commission, 2000) the European Commission established lifelong learning, both in its informal and formal senses, as a major asset for the Eurpoean Union, especially related to the tasks of regional development and integration, modernisation and the promotion of human capital and employability.

To understand the dangers and possibilities associated with recent models of learning in order to understand the sense in which theories of learning and power interact, we must understand Foucault's analysis of neoliberalism.

Neoliberalism refers to a particular economic model which in the context of this paper, pertains to the way that practices of economics and discursive patternings of knowledge and learning interact.

As a particular model of power it emerged as a revision of classical economic liberalism in the 1970s in the USA and Britain as a response to stagflation and the collapse of Bretton Woods system of international trade and exchange, leading to the abolition of capital controls in 1974 in America and 1979 in Britain (Mishra, 1999, Stiglitz, 2002).

These policies made it extremely difficult to sustain Keynesian demand management. Exchange rates were floated and capital controls abolished, giving money and capital the freedom to move across national boundaries.

Far from being an inevitable process reflecting the inevitable post-Fordist determinations of the economic, neoliberalism must still be understood as the deliberate policy of those in power.

As Paul Hirst (2000b: 179) states, the creation of markets has been engineered by particular policies. It was public policy, not market pressures, that led to the deregulation of capital markets and the removal of exchange controls in the late 1970s and early 1980s. As he states:

What is supposed to be an inevitable market-driven global process is actually substantially a product of public policy...It was influential economic policy elites and state officials in advanced states that shaped the deregulatory freemarket vision of world trade. 


\section{Foucault's analysis of neoliberalism}

In his lectures at the Collège de France in 1978 and 1979 Foucault focuses his attention on classical liberals such as Adam Smith, David Hume and Adam Ferguson, and two variants of post second world war neoliberals: the Ordoliberalen in Germany and the Human Capital theorists in the United States. (Lemke, 2001; Burchell, 1991, 1996; Foucault, 1982b, 1984, 1991, 1992, 1993,1997a, 1997b, 2001a, 2001b).

The Ordoliberalen comprised a group of jurists and economists in the years 19281930 who published in the yearbook Ordo. Amongst their numbers were included William Röpke, Walter Eucken, Franz Böhm, Alexander Rüstow, Alfred MüllerArmack and others.

Preaching the slogan that 'inequality is equal for all' they devised a social market economy influencing the shaping of West German economic policy as it developed after the war.

Foucault refers to these Ordoliberalen as the 'Freiberg School' who had some affinities (of time and place) with the Frankfurt School but were of a very different political persuasion. While they held that Nazism was a consequence of the absence of liberalism, they did not see liberalism as a doctrine based upon the natural freedom of the individual that will develop by itself of its own volition.

In fact, for the 'Freiberg School' the market economy was not an autonomous, or naturally self-regulating entity at all. As a consequence, their conception of the market and of the role of competition, says Foucault, is radically anti-naturalistic. Rather than the market being a natural arena which the state must refrain from interfering with, it is rather constituted and kept going by the state's political machine. Similarly, competition is not a natural fact which emerges spontaneously from human social intercourse, as a result of human nature, but must be engineered by the state.

As a consequence of this, the traditional distinction between a sphere of natural liberty and a sphere of government intervention no longer holds, for the market order and competition are engineered by the practices of government. Both the state and the market are on this conception artificial and both presuppose each other.

In Foucault's view such a conception means that the principle of laissez-faire, which can be traced back to a distinction between culture (the artificial state) and nature (the self-regulating market), no longer holds. 
For the Ordoliberalen, the history of capitalism is an institutional history. Capitalism is a particular contingent apparatus by which economic processes and institutional frameworks are articulated. Not only is there no 'logic of capital' in this model, but the Ordoliberalen held that the dysfunctions of capitalism could only be corrected by political-institutional interventions which they saw as contingent historical phenomena.

What this means, says Foucault, is that the Ordoliberalen support the active creation of the social conditions for an effective competitive market order. Not only must government block and prevent anti-competitive practices, but it must finetune and actively promote competition in both the economy and in areas where the market mechanism is traditionally least prone to operate.

One policy to this effect was to 'universalise the entrepreneurial form' (Lemke, 2001: 195) through the promotion of an enterprise culture, premised, as Foucault put it in a lecture given on $14^{\text {th }}$ February 1979, on 'equal inequality for all' (Lemke, 2001: 195).

The goal here was to increase competitive forms throughout society so that social and work relations in general assume the market form i.e., exhibit competition, obey laws of supply and demand. In the writings of Rüstow, this was called 'vital policy' ('Vitalpolitik' ) which described policies geared to reconstructing the moral and cultural order to promote and reward entrepreneurial behaviour, opposing bureaucratic initiatives which stifle the market mechanism.

To achieve such goals, the Ordoliberalen also advocated the redefining of law and of juridical institutions so that they could function to correct the market mechanism and discipline non-entrepreneurial behaviour within an institutional structure in accordance with, and supported by, the law. In this sense, the Ordoliberalen were not simply anti-naturalist, but constructivist. 


\section{Human Capital Theory}

In his analysis of neoliberalism, Foucault also directs his attention to the Chicago School of Human Capital theorists in America, focussing particularly on the works of Becker.

These neoliberals also opposed state interventionism when it was bureaucratic and supported it when it fostered and protected economic liberty. For Human Capital theorists the concern was the uncontrolled growth of the bureaucratic apparatus as a threat to the freedom of the individual.

Foucault sees the major distinction between the German and US neoliberals existing in the fact that in the US neoliberalism was much less a political crusade as it was in Germany or France, for in the US the critique was centrally directed against state interventionism and aimed to challenge the growth of the state apparatus.

In his lecture of March 28, 1979, Foucault discusses Hayek and von Mises (whom he labels as the "intermediaries of US neoliberalism"), Simons, Schultz, Stigler and Gary Becker, whom he says is the most radical exponent in the US.

The US neoliberals saw the Ordoliberalen as representing the political as being above and outside the market but constantly intervening to correct its bureaucratic dislocations.

From their viewpoint, they wanted to extend the market across into the social arena and political arenas, thus collapsing the distinction between the economic, social and political in what constitutes a marketisation of the state.

No longer is the state independent of and outside the market, but itself now subject to market laws. In doing this, the US neoliberals extend economic criteria into spheres which are not economic and market exchange relations now govern all areas of voluntary exchange amongst individuals.

In this model, the social and political spheres become redefined as economic domains. The government and the public sector will be 'economised' to reflect market principles and mechanisms. Thus the economic covers all of society and society is theorised as a form of the economic.

The task of government is to construct and universalise competition to achieve efficiency and invent market systems. As Foucault states, for the US neoliberals, the market becomes "a kind of permanent economic tribunal" ("une sorte de tribunal économique permanent') (Foucault, Lecture, March 21, 1979 - see Lemke 2001: 198) ${ }^{2}$. 
As Foucault sees HCT, it is concerned with the problem of labour in economic theory. While classical political economy claimed that the production of goods depended upon real estate, capital, and labour, neo-liberals held that only real estate and capital are treated appropriately by the classical theory, and that labour needs greater illumination as an active, rather than as a passive, factor in production.

In this sense neoliberals concurred with Marx that classical political economy had forgotten labour and thereby they misrepresent the process of production. In order to correct this deficiency, neoliberals theorise the role and importance of labour in terms of a model of human capital. In essence their theory starts with the human individual in terms of a classification of skills, knowledge and ability.

Becker distinguishes two central aspects to such human capital: (1) inborn, physical and genetic dispositions, and (2) education, nutrition, training and emotional health.

In this model, each person is now an autonomous entrepreneur responsible ontologically for their own selves and their own progress and position. Individuals have full responsibility over their investment decisions and must aim to produce a surplus value. As Foucault puts it in his March 14, 1979 lecture, they are "entrepreneurs of themselves"

As Graham Burchell (1996: 23-24) puts this point, while for classical liberalism the basis of government conduct is in terms of "natural, private-interest-motivated conduct of free, market exchanging individuals", for neoliberalism "the rational principle for regulating and limiting governmental activity must be determined by reference to artificially arranged or contrived forms of free, entrepreneurial and competitive conduct of economic-rational individuals".

This means that for neoliberal perspectives, the end goals of freedom, choice, consumer sovereignty, competition and individual initiative, as well as those of compliance and obedience, must be constructions of the state acting now in its positive role through the development of the techniques of auditing, accounting and management.

It is these techniques, as Barry, Osborne and Rose (1996: 14) put it:

[that] enable the marketplace for services to be established as 'autonomous' from central control. Neo-liberalism, in these terms, involves less a retreat from governmental "intervention" than a re-inscription of the techniques and forms of expertise required for the exercise of government. 
While there is thus an important difference between those forms of liberalism that existed from the seventeenth to the end of the nineteenth century and the forms of neoliberalism that emerged in the twentieth century, the special nature of the relationship between government and governed, and the priority of a market of free associations within this relationship, constitutes a central and continuous thread through the various different forms of liberalism. In this, as Burchell (1996: 23) points out, both early and later liberalism "set out a schema of the relationship between government and the governed in which individuals are identified as, on the one hand, the object and target of governmental action and, on the other hand, as in some sense the necessary (voluntary) partner or accomplice of government".

\section{Lifelong learning as an instrument of flexible governmentality}

In this context lifelong learning can be represented a particular technology of power in the same senses, indeed the same way, that public choice theory, agency theory, or cost-transaction economics can be seen as technologies of power.

Whereas the latter are global discourses pertaining to the management of public enterprises in market terms, lifelong learning represents a global discourse for the flexible preparation of subjects.

While our basic theoretical model is not narrowly functionalist, or economistic, it can be observed that at a certain level of analysis, a functionalist explanation works:

lifelong learning constitutes a specific technology which makes both the tertiary and non-tertiary labour force subject to a new form of flexible rationalistion which under national systems of Keynesian welfare nationalism never actually existed, which is to say, as Robert Boyer ( 1988: 258) has put it, that under Keynesian modes of regulation, the free development of global economies were "delayed because of a lack of social and technical means of controlling workers". It is the global production of infinitely knowledgeable subjects that the technology of lifelong learning enables. It thus represents a specifically global and non-Keynesian means of constituting workers as knowledgeable subjects.

The emergence of the technology serves in these senses as both cause and effect. On the one hand it enables both the individualisation of responsibility for education or learning, and on the other it enables the abolition of welfare obligations of states.

In this sense, the technology of lifelong learning enabled a downgrading of social rights within any particular national territory in preference for a global level playing field characterised by equality of opportunity. 
Its main strength is that it constitutes a flexible technology in a number of senses.

First, it enables businesses and governments to avoid direct responsibility;

second it enables the adaptability of workers in terms of their mobility within the workforce between businesses and countries.

It thus enables the ability of workers to move from one job to another within a given overall production process, or within a production process that can switch between products and skills and which can itself be transitory.

This kind of flexibility requires skill and competence of a potentially short term nature, features which did not characterize Taylorism or Fordism ${ }^{3}$.

The key strategy, of which lifelong learning is a component is that of "workforce versatility", which enables high levels of job mobility, premised on a high level of general and technical training and a ready ability to add new skills in order to make change possible.

The lifelong worker thus equates directly with Proudhon's "ideal worker" (l'ouvrier proudhonien).

As a strategy, then, lifelong learning enables a growth in the permissiveness of legal restraints over conditions of work and employment, especially dismissal, within particular national boundaries.

It translates as a proposal to increase the laxity of controls over employee rights and safeguards with regard to job security or protection ensuring an automatic mechanism of worker adaptability which reduces workers ties to a particular company or business by making the employment contract itself more flexible.

A new regulatory environment is produced which increases the mobility of capital lessening its dependence on the traditional employment contract and absolving the establishment or company of responsibility for security and welfare.

A new technology of flexible adaptation ensures that responsibility for employment tenure belongs to individuals themselves, ensures the possibility for companies to offset responsibility for social and fiscal payments, and enhances the freedom of business in a global environment.

Paradoxically, such flexibility, as Robert Boyer (1988: 227) states, helps maintain the stability of certain aspects of economic life. 
Hence discourses such as lifelong learning assist in stabilising work-individual relations by enabling the system or sub-system to respond to a variety of disturbances.

It substitutes for the rights of workers over education and entitlement to knowledge an automatic system based on the ready availability of information and skills.

Thus lifelong learning involves a re-structuring of the context of education in the interests of efficiency through flexibilisation. As Tuschling and Engemann (2005) state:

The purpose is not to de-institutionalize but rather to inter-institionalize learning. [This involves]...1. changing the field of learning in order to totalize learning to all imaginable situations. 2. initiating a change in the selfperformance of individuals that they act as learners in all imaginable situations. With these two components the learning individual is configured as an interinstitutional entity traversing situations and institutions, obliged to strategically show knowledge and skills. Especially non-formal and informal learning have to be presented as accessible and manageable. This is the task of the third component of inter-institutionalization: the techniques that allow both individuals and institutions to inscribe, store, process and transfer actions as learning. The main activities of the European Union in this field are centred around these techniques. It is within them that lifelong learning is getting a density and becomes most palpable.

\section{From knowledge to information}

Building upon the analysis above, as James Marshall (1996: 269) has noted, what is substituted in the neoliberal discourse of lifelong learning is knowledge for

\section{information:}

knowledge has been replaced by skills and learning. Everything which might have been seen as obtaining knowledge - an object of an activity - seems to have moved into an activity mode, where what is important is process

In this, as Bert Lambeir (2005: 350) notes, "the bond between the information society and the learning society appears to be a very tight one". As learning has been redefined in terms of process, and functions as information, it needs to be continuously relearned, readjusted and restructured to meet the needs of the consumer in the service information industry.

Learning in this sense is an ongoing permanent addition of competences and skills adapted continuously to real external needs. 
As Lambeir (351) states, "Learning now is the constant striving for extra competences, and the efficient management of acquired ones. Education has become merely a tool in the fetishisation of certificates".

The continual availability of information adapts learning and knowledge to the changing context of flexible production. In this sense, to echo Richard Edwards (1997: Chp. 2) it accommodates a world of constant change where the imperative or possibility of updating our knowledge and skills again and again and again in order to anticipate all possible transformation

It is in this sense that the discourse of lifelong learning is a call for "permanent education" (Lambeir, 2005: 350). As Lambeir continues:

Lifelong learning is the magic spell in the discourse of educational and economic policymakers, as well as in that of the practitioners of both domains. The Flemish minister of education for example declares lifelong learning to be one of the government's priorities. She argues for equal learning opportunities for every individual, to encounter the threatening duality between those that did learn and still do, and those who do not use the educational facilities. In order to meet this goal individualised learning advice and support will be necessary. In this respect we might consider the following: first, learning activities must be presented as enjoyable, and related to the adult's curiosity and to the creation of new opportunities. Second, there is a need to set up a 'digital learning mall', a database which provides an overview of the learning opportunities offered in the country. Finally, the opportunity to use information and communications technology to offer more flexible and need-orientated learning facilities, must be explored.

Lifelong learning accommodates the global provision of education and skills on the basis of equality of opportunity, inclusiveness, emphasising the importance of key qualifications, basic skills and primary knowledge.

As Lambeir notes, this is provided on the basis of "self-managed learning" incorporating a shift from "offer-orientated" to "question-orientated" education, or in Marshall's terms, from knowing that to knowing how in which learning becomes nothing more (or less) than the public collection of competencies offered in the labour market of learning opportunities.

While many of these are useful, one can never have enough, and one can never have enough fast enough. In this sense, lifelong learning is a market discourse that orientates education to the enterprise society where the learner becomes an entrepreneur of him/herself. What she becomes depends solely on herself and the choices she makes. She is responsible for herself. Such a model requires skills of selfmanagement and record keeping so that demonstrations of established learning are rendered transparent through audit. 
Ultimately lifelong learning shifts responsibility from the system to the individual whereby individuals are responsible for self-emancipation and self-creation. It is the discourse of autonomous and independent individuals who are responsible for updating their skills in order to achieve their place in society.

For Foucault lifelong learning would constitute a new technology of power and part of the mechanisms of control operating in our society. It is a discourse which aims at resolving the individual and the general; omnes et singulatum, in the interests of the smooth functioning of the whole.

As well as constituting a strategy of government at the policy level, lifelong learning also constitutes a form of bio-power in that it aims to discipline subjects. Marshall (1995: 322) has proffered the term busno-power which can be represented as characterising a particular form of bio-power. Busno-power:

Is directed at the subjectivity of the person, not through the body but through the mind, through forms of educational practices and pedagogy which, through choices in education, shape the subjectivities of autonomous choosers....this busno-power also impinges upon the population as a whole, as individual consumer activity "improves" both society and economy.

Busno-power thus represents a distinctively neoliberal form of bio-power which constitutes individuals as autonomous choosers of their own lives. In this model, then, lifelong learning embodies new techniques of self-regulation and aims to minimize the "time lag" between skills and individual development and economic and technological change (Kraus, 2001: 17; cited from Tuschling and Engemann, 2005).

While lifelong learning implies an active as opposed to passive learner, when viewed in relation to neoliberal agendas it implies a shift in the control of authority for education from the collective to the individual, involving increasing responsibility of the individual for educational and work careers and the skills required and outcomes that ought to take place. Getting prepared is now more in the hands of the individual which entails greater risk in that the individual has to "co-finance his own learning" (Commission of the European Union, 2000: 15, cited from Tuschling and Engemann).

Hence, as Anna Tuschling and Christoph Engemann (2005: 6) note:

lifelong learning means self determination and self-responsibility in educational tasks, including the financial aspects...the lifelong learning discourse identifies a broad need to teach individuals to become autonomous learners. 
As such, say Tuschling and Engemann (citing Gerlach, 2000: 189), lifelong learning represents an "internalized educational aspiration", where the individual is not only responsible for the content of the knowledge, but also for the levels and structures and process and organisation.

Essentially the learner becomes the entrepreneurs of their own development. What the states provide are the tools that facilitate the process. Not only must the individual learn, but they must learn to recognise what to learn, and what and when to forget what to learn when circumstances demand it, they say. They go on to cite Deleuze (1990) who characterizes the field of control in terms of "limitless postponements", where "perpetual training" replaces specified levels, in what are characterized as techniques of "permanent self performance". They then state:

The ability to orientate oneself in such a manner is condensed in the second core concept of lifelong learning, the so-called social competences and key qualifications...terms that point to basic self-organisational dispositions... of being able to interpret their own circumstances, self-directed in a way that leads to learning.(p.6)

\section{Learning for democracy}

In one important sense, we are all, or should be all, inhabitants of a future learning society.

The key question becomes for what purposes is learning to be readily available, what ends should it serve. If it is simply "fast food for the brain" (Lambeir, 2005: 354) or concerned narrowly with cognitive and metacognitive skills in the interests of adaptability to the world of work and the constantly changing demands of capital then it becomes a means of enabling business to minimise or avoid its social responsibilities by offloading the social and educational costs of production in a constantly changing technological environment.

The sort of learning society needed today is one that orientates learning and knowledge to survival.

The continuance of traditions and customs which enable individuals to function effectively as members of communities requires not the endless addition of skills and information, but a progressive deepening of the political arts of democratic communication and negotiation through the skills of deliberation, contestation and debate. 
Learning must move away from a concern with quantitative addition of cognitive and metacognitive skills to a concern with qualitative transformation of the subject through their active engagement in the educational process. Such a process does indeed involve accessing new information, adding new skills, but such a process must be in the context of active participation and engagement in the democratic structures through which the conflicts between individuals and society are accommodated, and through which change and transformation are effected.

Clearly any meaningful idea of the learning society must embody, or express, principles that transcend the nation-state and embody principles of the free development of all peoples.

This can be expressed as embodying the principles of cosmopolitanism which involves learning as a process of engagement with the "other". The commitment to cosmopolitanism embodies a commitment to reason and human rights in an equal distribution of the chances and prospects of survival.

Self-organised learning certainly has a place in this scenario. But also essential are the twin values of freedom and participation as embodied, for instance, in Dewey's pragmatism where learning embodies a mode of life where reason is exercised through problem-solving where the individual participates and contributes to the collective good of society and in the process constitutes their own development. In this model, the learning society is a global society of engagement.

The learner is engaged in a process of action for change as part of a dialogic encounter rather than as a consequence of individual choice. Popkewitz, Olsson and Petersson (2005: 2) refer to this project as founded upon an "unfinished cosmopolitanism" where learning is talked about as "planning one's biography as continuously solving problems, making choices and collaborating in "communities of learners' in a process of cultural innovation". They use the term 'unfinished cosmopolitan' rather than the phrase 'lifelong learner' is in order to "historicize the present”.

Yet, it effects more than that, for just as it makes the individual inseparable from the collective, or rights inseparable from duties, so it makes learning inseparable from teaching. Hence learning is inseparable, as Wagner (1994: xiv) writes, from "the substantive foundations of a self-realisation and of shifting emphasis between individualised entitlements and public/collective capabilities" (cited in Popketwitz, et al., 2005). 
For Popkewitz et al (2005):

The narratives of the unfinished cosmopolitan as the Learning Society embody new relations between individuality (the lifelong learner) and the social. The fabrication of the child as a problem solver no longer sediments responsibility in the range of social practices directed towards a single public sphere. The new individuality traverses diverse and plural communities to constitute the common good...Reason is no longer for the perfection of the nation as the collective embodiment of the social good. Change, contingency and uncertainty in daily life are tamed through the rules and standards that place the problem solving child in diverse communities where the common good is formed...The unfinished cosmopolitan...is orientated to the future through unfinished processes that are viewed as expressing universal human attributes of reason, science and progress. The unfinished cosmopolitan problem solves to chase desire and works in a global world in which there is no finishing line.

In this new field, say Popkewitz et al (2005), the learning society no longer functions as an educational ideal, but as a political one. In this sense, learning is integrally related to community, and as the systems of communication and language through which participation and learning take place are by their very nature social. Such a theme links directly to democracy as the mechanism through which individual and collective are mediated. As the techniques such as deliberation and contestation, which enable this mediating transference are themselves only learnable in the context of participation and engagement, learning is itself a constitutive democratic project

\section{Global learning as democratic participation}

If learning is now represented as social and political engagement in a global community, it constitutes a form of participation.

In liberal theory participation was represented as optional for the individual who was defined as ontologically existed prior to, and therefore outside of, the political community.

In a social view of selfhood participation is coterminous with any form of agency whether in language, or communication, or institutional engagement.

Given the exclusionary and disequalising tendencies of power, participation theory strives to enumerate more or better quality of inclusion. As well as permit inclusion, any adequate conception must promote a specific conception of involvement, pertaining to the uptake of skills and knowledge in order to empower their lives and others. 
In this sense participation involves learning in a mutually reciprocal process as the basis of survival in a constantly changing global society.

Participation also requires a theory of freedom or liberation.

As each individual is interconnected with others and the structures of support, the free action of each is linked to the free action of all.

Yet for participation to enable freedom it must be democratically structured.

If post 9/11 makes learning for democracy of more pressing concern; our conception has moved a long way from a narrow theory of universal enfranchisement.

To the extent that counter-terrorist action now constitutes an important item, it must itself be subject to the democratic norms of public visibility and critical scrutiny, together with open processes of deliberation and debate, as well as traditional rights of contestation in terms of the rule of law.

If our substantive conception posits certain general ends, which allow for a degree of diversity and pluralism, our procedural view of democracy is as a multifaceted array of mechanisms and processes instituted to ensure the inclusion, security or safety as well as development and opportunities of all individuals and groups.

In this respect research needs to focus of the means of deepening democracy to satisfy these goals. As a way of concluding this article, it might look to include research on all or any of the following themes:

- The concern with equality: the development of any conception of democratic justice embodying a concept of learning must seek to deal rather than avoid issues to do with distribution of resources and life chances.

- Learning as participation in the global community is not possible except where resources and human needs are satisfied. It is important to theorise the implications of a social ontological framework of community for considerations of democratic justice as it pertains to distributional ethics if the learning community is to be a reality. Community in this sense is definable as an all-encompassing arena without fixed borders or unity, which comprises an assortment of values, norms and institutions that enable life to be lived.

- Such a conception of community recognises social ties and shared values, as well as practices of voluntary action and public institutions like education which constitute the conditions for stability and reproduction of society. 
- Although neoliberal philosophers like Robert Nozick (1974) have shifted political philosophy away from a concern with issues of distributive justice in recent years, my own view is similar to the nineteenth century social democrat L.T.Hobhouse who held that ones entitlement to rewards and gain must be balanced by one's obligation to society.

- What liberal conceptions of democracy obscured, in Hobhouse's view, was the inter-dependence between individuals and the social structure or for the social and moral obligation of the society (acting through the vehicle of the state) to assist in arranging the social futures of each rising generation. As he argued in his book, Liberalism (1911: 189-190), in his justification for redistributive policies of progressive taxation, the state has an obligation to enforce reasonable conditions of equality on the basis that while a society should provide the conditions for learning and enterprise, all individuals are correspondingly indebted to society for the conditions and structures provided, and on this basis, individuals should contribute in direct proportion to the luck or good fortune they experience.

- The role of the state: The role of the state should be concerned with guaranteeing access to education and knowledge, as well as information and skills as a fundamental right.

- The state's obligations as regards learning involve it in developing opportunities based on people's rights to inclusion and the development of their capacities. This obligation gives the state a role in the provision of social services, health care, and education. In brief, the role for the positively geared state lies in relation to socially directed investment decisions, to provide for the general conditions for all species needs and development, including education and training, and to create and maintain quality infrastructure such as schools, hospitals, parks and public spaces and learning opportunities.

- The development of civil society: Civil society refers to that sector of private associations relatively autonomous from the state and economy, which spring from the everyday lives and activities of communities of interest. It is clearly pivotal for learning. Clearly, one principle of democracy is the idea of deliberation encompassing learning in the arts of dialogue. Another principle of democracy is the right to contest, challenge or oppose. If democracy is rule by the people, the ability, and opportunity to "speak the truth to power", as Michel Foucault (2001) has put it, is itself one of democracy's crucial rights, indeed its very condition. 
- The role of education: the role of education is crucial for learning for democracy, as educational institutions, whether compulsory or post-compulsory intersect with, and therefore mediate between institutions like the family and those of the state and the economy.

- Although formal institutions of education have been in the main public institutions, there is an important sense in which they are semi-autonomous from the state.

- This is not the neo-liberal sense where management and administration are devolved to the local school, but the sense in which the school's are located in, and represent local community groups. In this sense, schools are important as democratic organisations, through the particular way that they are connected to communities, through their ability to empower families, and involve minority groups in participatory projects.

- Education also is crucial as the central agency responsible for the production of democratic norms such as trust and political decision-making. This is to say, as Mill (1910) recognised in Representative Government, educational institutions are important as sites where democracy and self-government are learnt.

- Deliberative democracy is especially complex, for it involves not just norms and procedures of debate but norms and procedures of contestation, inclusiveness, tolerance, compromise, solidarity with others, generosity, care, the operations of forums, and of checks and balances, the use of sanctions and screens, and the separation of powers.

- In the republican tradition, schools are instrumental in the development of civic virtue and habits of good citizenship. This is what signals the real importance of the "knowledge economy". For education is essentially important in its role of constructing democratic civic norms, and this must become one of the central aims of Government policy in this regard. It is not a case of 'brainwashing' or 'socialisation' but of teaching skills and establishing models of civic conduct based on tolerance, deliberation, conflict resolution, give and take, and trust. While educational processes depend upon fairness of political processes, and in the distribution of economic resources, education is necessary to construct the network of norms that permit both the market and democracy to function. As Philip Pettit (1997: 255) puts it, education represents a "stark choice between the invisible hand and the iron hand: between a strategy of marketing and a strategy of management". It is this reason of course why education should ideally be public, universal compulsory and free. For if education is vital in constructing norms that nurtures the market, it cannot be itself subject to the market's disorganising effects. 


\section{References}

Boyer, R. (1988) The Search for Labour Market Flexibility. Oxford: Clarendon Press.

Burchell, G. (1991) 'Peculiar Interests: Civil Society and Governing "The System of Natural Liberty", in G. Burchell, C. Gordon, and P. Miller (eds.), The Foucault Effect: Studies in Governmentality. Chicago: The University of Chicago Press.

Burchell, G. (1996) 'Liberal Government and Techniques of the Self', in A. Barry, T. Osborne, and N. Rose (eds.), Foucault and Political Reason (pp.19-36). Chicago: University of Chicago Press.

Edwards, R. (1997) Changing places? : flexibility, lifelong learning and a learning society. London: Routledge.

European Commission (2002) European Report on Quality Indicators of Lifelong Learning. Brussels.

Foucault, M. (1982) The Subject and Power. Afterword in H.L.Dreyfus and P. Rabinow, Michel Foucault: Beyond Structuralism and Hermeneutics $\left(2^{\text {nd }}\right.$ edn.). Chicago: University of Chicago Press.

Foucault, M. (1982a) Le subject et le pouvoir, in D.Defert, F.Ewald, and J. Lagrange (eds) Dits et écrits IV 1980 - 1988. Paris: Gallimard, pp. $222-243$.

Foucault, M. (1982b) 'Michel Foucault: Vorlesungen zur Analyse der Machtmechanismen 1978' (partially complete transcription of a lecture given at the Collége de France in 1978), translation in German by Andreas Pribersky in Der Staub und die Wolke, Bremen: Impuls, pp.1-44, cited from Thomas Lemke (2001).

Foucault, M. (1984) 'Politics and Ethics: An Interview' (trans. C. Porter), in P. Rabinow (ed.) The Foucault Reader, New York: Pantheon, pp. 373-380.

Foucault, M. (1991) 'Governmentality', in Graham Burchell, Colin Gordon and Peter Miller (eds.) The Foucault Effect: Studies in Governmentality. Chicago: The University of Chicago Press, pp. 87-104.

Foucault, M. (1991a) Remarks on Marx: Conversations with Duccio Trombadori. Trans. R.James Goldstein and James Cascaito. New York: Semiotext(e)

Foucault, M. (1992) 'La Population' (transcription of lecture of $25^{\text {th }}$ January 1978 rendered by Stéphane Olivesi), in Memoire de DEA de philosophie sous la direction de Monsieur P. Macherey, Universite de Paris I, Annee 1991- 1992, in Foucault Archive [A 271], [cited from Thomas Lemke (2001)].

Foucault, M. (1993) 'About the beginning of the hermeneutic of the self' (transcription of two lectures in Dartmouth on 17 and 24 November 1980), ed. Mark Blasius, Political Theory 21 (2): 198-227. 
Foucault, M (1994a) 'Two Lectures' [orig. published in 1976], in M. Kelly (ed.) Critique and Power: Recasting the Foucault/Habermas Debate. Cambridge,Mass.: MIT Press.

Foucault, M. (1997a) 'Security, Territory, Population', in P. Rabinow (ed.) Michel Foucault: Ethics, Subjectivity and Truth. London: Penguin, pp. 67-71.

Foucault, M. (1997b) 'The Birth of Bio-Politics', in Paul Rabinow, (ed.) Michel Foucault: Ethics, Subjectivity and Truth. Allen Lane: The Penguin Press, pp. 73-79.

Foucault, M. (1997c) On the Government of the Living, in Paul Rabinow, (ed.) Michel Foucault: Ethics, Subjectivity and Truth. Allen Lane: The Penguin Press, pp. 81-85.

Foucault, M. (2001) Fearless Speech. Ed. J. Pearson. Los Angeles, CA: Semiotext(e)

Foucault, M. (2001a) "Omnes et Singulatim": Toward a Critique of Political Reason', in James D. Faubion (ed.) Michel Foucault: Power, The Essential Works 3. Allen Lane: The Penguin Press, pp. 298-325.

Foucault, M. (2001b) 'The Risks of Security', in James D. Faubion, (ed.) Michel Foucault: Power, The Essential Works 3.Allen Lane: The Penguin Press, pp.365-381.

Gerlach, C. (2000) Lebenslanges Lernen. Konzepte und Entwicklungen 1972 bis 1997. Köln: Boehlau.

Hirst, P. (2002) Globalization, the Nation-State and Political Theory, in N. O'Sullivan (ed) Political Theory in Transition. London and New York: Routledge, pp. 172 - 89.

Hobhouse, L. (1911) Liberalism. London: Williams and Norgate.

Kraus, K. (2001) Lebenslanges Lernen. Karriere einer Leitidee. Bielefeld: W. Bertelsmann.

Lambeir, B. (2005) Education as Liberation: the politics and techniques of lifelong learning. Educational Philosophy and Theory, 37 (3) pp. 349 - 356.

Lemke, T. (1997) Eine Ktitik der politischen Vernunft. Foucault's Analyse der modernen Gouvernementalitat. Berlin/Hamburg: Argument.

Lemke, T. (2001) ' "The birth of bio-politics': Michel Foucault's lecture at the College de France on neo-liberal governmentality', Economy and Society 30(2): 190-207.

Marshall, J. (1995) Foucault and Neo-Liberalism: Biopower and Busno-power. In A. Neiman (ed.) Philosophy of Education 1995, Proceedings of the Philosophy of Education Society, Illinois: Philosophy of Education Society, pp. 320 - 329.

Marshall, J. D. (1996) Education in the Mode of Education: Some philosophical considerations, in Philosophy of Education 1996, Proceedings of The Philosophy of Education Society, Illinois: Philosophy of Education Society, pp. 266 - 276. 
Mill, J.S. (1910) Representative Government. New York: Everyman

Mishra, R. (1999) Globalization and the Welfare State. Cheltenham: Edward Elgar.

Nozick, R. (1974) Anarchy, State and Utopia. Oxford: Blackwell.

Peters, M. (2001) Education, Enterprise Culture and the Entrepreneurial Self: A Foucauldian Perspective. Journal of Educational Enquiry 2 (2), pp 58-71.

Pettit, P. (1997) Republicanism: A Theory of Freedom and Government. Oxford: Oxford University Press.

Popkewitz, T., Olsson, U., and Petersson, K. (2005) The Learning Society, the Unfinished Cosmopolitan, and Governing Education, Public Health and Crime Prevention at the Beginning of the $21^{\text {st }}$ Century. Forthcoming in Educational Philosophy and Theory.

Tuschling, A and Engemann, C. (2005) From Education to Lifelong Learning: the emerging regime of learning in the European Union. Educational Philosophy and Theory, forthcoming.

Stiglitz, J. (2002) Globalization and Its Discontents. London: Penguin.

\footnotetext{
${ }^{1}$ The English Translator states that "Foucault is playing on the double meaning in French of the verb conduire - to lead or to drive, and se conduire - to behave or conduct oneself, whence la conduite, conduct or behaviour. (See Foucault 1982: 221, note 2)

${ }^{2}$ My analysis relies on Lemke $(1997,2001)$ and on Foucault (1997b)

${ }^{3}$ Taylorism characterized wage/labour relations that slowly emerged in industry during the later years of the nineteenth century based on fragmentation and competition, while Fordism describes relations that became dominant since the 1950s, which prolonged the Taylorist mode through mechanization and factory organisation. (see Boyer, 1988)
} 